Article

\title{
Framing the EU: Big Data Analysis of South Korean News Media
}

\author{
Sung-Won Yoon ${ }^{1}$ and Sae Won Chung ${ }^{2, *}$ (D) \\ 1 Division of Business Administration, The University of Suwon, Hwaseong 18323, Korea; syoon@suwon.ac.kr \\ 2 Division of International and Area Studies, Pukyong National University, Busan 48513, Korea \\ * Correspondence: saewon.chung@pknu.ac.kr
}

check for

updates

Citation: Yoon, S.-W.; Chung, S.W. Framing the EU: Big Data Analysis of South Korean News Media. Sustainability 2021, 13, 1621. https:// doi.org/10.3390/su13041621

Academic Editor:

Amalia Triantafillidou

Received: 28 December 2020

Accepted: 29 January 2021

Published: 3 February 2021

Publisher's Note: MDPI stays neutral with regard to jurisdictional claims in published maps and institutional affiliations.

Copyright: (c) 2021 by the authors. Licensee MDPI, Basel, Switzerland. This article is an open access article distributed under the terms and conditions of the Creative Commons Attribution (CC BY) license (https:/ / creativecommons.org/licenses/by/ $4.0 /)$.

\begin{abstract}
Since 2010, both South Korea and the European Union have rapidly developed their diplomatic ties by completing a Free Trade Agreement and establishing a strategic partnership. However, perceptions of the European Union (EU) among Korean elites, media, and public have not been properly established. Against this backdrop, it is of value to examine the news media, which are the main sources of information for elites and the public. The purpose of this study is to examine the evolution of representations of the EU among South Korean media. To examine media representation, this study employed a quantitative methodology (semantic network analysis) for reviewing the data and a qualitative methodology (framing analysis) to interpret the results. The results of this study indicate that both conservative and liberal media employ conflict, economic consequences, and human interest framings to report EU issues. Despite some minor changes, neither type of media demonstrated clear differences in their EU coverage. The conclusion presented in this paper states that the South Korean media projects an incomplete picture of the EU to the Korean public. To overcome this issue, both South Korea and the EU should pay more attention to establishing accurate mutual perceptions to support a constructive future for their bilateral co-operation.
\end{abstract}

Keywords: South Korea; the EU; perceptions; media representations; big data analysis

\section{Introduction}

Since 1963, official diplomatic ties established between Europe (from the European Economic Community to the European Union) and South Korea have developed and continued to expand throughout the past half century. The mutual economic dependence between the European Union (EU) and South Korea has become more visible since the successful implementation of the free trade deal in 2011. As of 2018, South Korea is the EU's eighth largest export market and the EU is South Korea's third largest export destination [1]. Moreover, politically speaking, the bilateral relationship has evolved into a strategic partnership. as the Korean government officially recognised the EU as a "strategic partner" in 2010. Accordingly, such a noticeable evolution has led to the enhancement of the EU's visibility in the eyes of the South Korean news media.

As evidenced by the previous related research, perceptions of the EU in South Korean news media have become more salient over time in terms of volume and topics. Related studies include Chaban et al. (2004) [2], Chaban and Chung (2009) [3], Yoon, Chaban and Chung (2010) [4], Yoon and Lai (2015) [5], Public Policy and Management Institute (PPMI) et al. (2015) [6], and more recently Yoon (2020) [7]. These have commonly concluded that EU news coverage has become more frequent and diversified and the Korean audience has come to perceive the EU as not only an "economic giant" but also a "growing and highly expected global power" in normative fields.

Here, this paper presents comprehensive analysis of South Korean media perceptions concerning the EU. This is a "comprehensive" study in two respects: first, the data collection time period is comprehensive. Data collected for the ten years from July 2010 to June 2020 encompasses most EU-related news reports in conventional newspaper outlets. Second, the study analysed six representative newspapers, The Chosun Ilbo, The Dong-A 
Ilbo, JoongAng Daily, Hankook Ilbo, The Hankyoreh, and Kyunghyang Shinmun, due to their political parallelism. Three newspapers (The Chosun Ilbo, The Dong-A Ilbo, and JoongAng Daily) are typically classified as "conservative" newspapers and the other three (Hankook Ilbo, The Hankyoreh, and Kyunghyang Shinmun) are considered "liberal" [8]. Such political parallelism is considered one of the important dimensions of the media system $[9,10]$. By analysing news stories from both the conservative and progressive media, it is possible to investigate comprehensively how the EU has been represented by South Korean news media over the past decade and whether different political orientations in the media have affected the image of the EU.

South Koreans rely heavily on online sources for their news. As of 2020, $83 \%$ access news from online news portals [11] (p. 6, p. 102) such as Naver (62\%) and Daum (32\%), which are referred to in particular as preferred news sources [11] (p. 102). Additionally, these online news items are also shared through different social media platforms such as Facebook, YouTube, and so on. In particular, most online media producers own YouTube accounts to disseminate their messages to wider audiences in Korea. All the conventional newspaper companies run online news sites; however, South Koreans prefer visiting online portals where they can see all the news from different news outlets at once. Since these portals receive news articles from the media and upload them without changes, the news displayed on the portals is identical to the news in the respective online news sites. Access to the massive collection of EU-related news in South Korea would enable an analysis of the way that the image of the EU has been shaped and disseminated for the past decade, as well as how such image creation has affected South Korean perceptions of the EU.

Behind the sound development of the EU-Korea relations, the EU has faced multiple crises, such as the Eurozone crisis; the refugee crisis; Brexit; the surge of the far right in other member states; and, most recently, the COVID-19 pandemic. EU images in South Korean media have turned negative from the mid-2010s [12]. This phenomenon was spotted from the results of the project named "Analysis of the perception of the EU and of EU's policies abroad" [13] supported by the European Commission. In this project, South Korean media analysis results were reflected. Park and Chung implied that the Korean media started to communicate with their audiences about the EU regarding its crises rather than the beneficial potential of EU-Korea cooperation [12]. Such a topic change in communication between the media and the public informs us that South Korean media employed the crisis communication mode in covering EU affairs. Especially after the Brexit referendum in 2016, think-tanks and other experts presented research papers on the prospects of Brexit's possible impact on the South Korean economy and EU-Korea relations [12]. Hence, as a starting point for investigating crisis communication through social media, looking into the EU coverage in the South Korean legacy media, which is one of the major sources of information on social media, can be helpful.

This study aims to probe the evolution of the EU's representation in South Korean news media by focusing on framing evolution. The data set consists of EU-related articles published in major newspapers as sources of crisis communication through social media over the past ten years (July 2010 to June 2020). Data collection was achieved by researchers employing the Korean Government's Big Data Platform (BigKinds) and data collecting software (UiPath). Subsequently, the data were analysed and visualised using text mining software (NodeXL). Based on the results, this study illuminates the evolution of framing changes throughout the research period. The qualitative framing analytic model by Semetko and Valkenburg is employed to allow more in-depth discussion [14].

\section{Theoretical Background}

In considering EU global media representation, image theory, suggested by Silverstein and Flamenbaum (1989) in an international relations context [15], is helpful in understanding "a complex mix of international actors' perceived intension, capabilities and cultural and political status" [16] (p. 9). Image theory in international relations was established in order to guarantee a suitable analytical framework for measuring how global actors 
perceive each other. Silverstein and Flamenbaum exemplified this theory in the case of the US-USSR conflict during the Cold War [15]. During the period, both the US and the USSR did not have sufficient information, so the political elites, the media, and the general public had biased images, leading to conflicts and further changes in international relations [15]. After the Cold War, this theory has been updated to explore the case of the War on Terror [17] and to examine national security policy [18]. Mišík suggested that there are three main dimensions of images and perceptions of a particular state: (1) relative power, (2) goal compatibility, and (3) cultural distance [19]. These dimensions provide a useful conceptual framework to discuss some beneficial questions about Korean perceptions of the EU. For relative power, we could explore whether the Korean media describes the EU's relative power status on the global stage. For goal compatibility, the South Korean media representations of the EU indicate the mutual interests between the EU and South Korea. Such compatibility would also help draw helpful suggestions for the development of EU-Korea bilateral relations. For cultural distance, we can address what could be potential barriers between the two parties. Examples can be found from these parties' historical pasts (such as wars, conflicts, or colonial experiences).

The EU images projected in South Korean media have been researched since the mid-2000s. The representative research examples can be found in Chaban et al.'s work (2006) [2] and Chaban, Yoon, and Chung's study (2010) [4]. Recently, from the end of the 2010s, Chung looked into EU images in social media [20-22]. Chung specifically gave attention to exploring how images of the EU are formed on social media, especially focusing on YouTube in terms of information dissemination [20] and the semantic structure of YouTube postings using analytic software [21,22]. In terms of methodology, different from past research Chung employed analytic software to analysed unstructured data on the internet space to explore Korea's perceptions of the EU. In contrast to the methodological and research innovation, the results were not satisfactory because there an insufficient amount of EU-related YouTube videos were filmed in Korean languages. Additionally, Chung pointed out that South Korean viewers did not pay much attention to the EU, so their number of viewers of EU-related videos was not high enough [20]. This study pays attention to news agencies' portrayal of the EU as a prominent source of EU images on social media. After the analysis, this study's results section discusses South Korea's social media crisis communication mode regarding the EU's multiple crises.

In exploring EU images or representations in the global media, it is helpful to consider the agenda-setting theory. This theory covers the news media's impact in forming the public agenda-public awareness and concern regarding salient issues generated by the news media [23]. McCombs and Shaw of the University of North Carolina at Chapel Hill established the "agenda-setting theory", which looks at how the media shapes the political reality within the general public's understanding or perception [24]. Based on this theoretical viewpoint, other scholars such as Hastie and Park [25], Iyeanger and Kinder [26], Iyeanger [27], and Scheufele and Tewksbury [28] suggested that people tend to think or make judgments based on the availability of data or information provided from the news media. Based on this theoretical perspective, the results present the salient issues arising from the coverage of the EU in the Korean media from 2010 to 2020. Subsequently, the data will be discussed together with the public opinion survey results to make an argument about effects of the media on public awareness about the European Union. In considering this overview of media representation, framing theory would be useful. However, as Price and Tewksbury argued [29], it would not be useful to consider media framing (applicability) and agenda-setting (accessibility) together. To resolve this issue, we are going to restrictively address media framing as a unit of analysis and explain this more in the framing analysis section (Section 3.2.2).

For addressing the crisis communication mode of EU representation in Korean media, it is useful to consider Coombs' categories of crisis management within the vast area of crisis communication theory. As mentioned above, the Korean media began to talk about the EU's crises with their audiences in the mid-2010s. Coombs explained that 
crisis management is about recognising reputational capital [30]. Extending Fombrun and van Riel's account [31], crisis management is similar to keeping the reputational capital of a certain organisation. It is a metaphorical expression of a reputation as assets in a bank account $[32,33]$. Coombs further explains that "a favourable prior (pre-crisis) reputation is a buffer against the reputational capital lost during a crisis" [30] (p. 165). Coombs suggested that there are three phases of crisis communication: pre-crisis (preparatory and preventive communication phase ahead of time for crisis management), crisis responses (responses to an actual crisis), and post-crisis (communication occurs after the crisis has been resolved) [30]. Based on this point, this paper attempted to further explain the stage of crisis communication and to examine whether the EU had a favourable reputation in the past.

\section{Materials and Methods}

\subsection{Materials}

The data set consisted of collected EU-related news items from six major Korean newspapers published over ten years since the launch of the EU-Korea strategic partnership in 2010. EU-Korea relations had a sluggish development from the beginning of their bilateral relations up to 2010. During the negotiation of the EU-Korea Free Trade Agreement (FTA), South Korea showed great expectations from having the EU as a closer trade partner for their desirable future cooperation [34]. Chung and Lee claimed that EU-Korea bilateral relations have actively developed since the partnership [34]. Recalling the claim made by Park and Chung [21], South Korea began to notice and sensitively react to the EU's crises in order to measure the possible impacts. Consequently, we set the year 2010 as the starting point of our data collection. For exploring South Korea's crisis communication exercise, the period can be set according to the union's major disruptions and crises. Based on major events, the whole data collection period can be divided into three sub-periods to describe the dynamics of media frames arising within EU news coverage. Table 1 presents an overview of the data collection period classifications and their major events. The first period is classified as an "expectation" period (July 2010 to June 2013), when the EU-South Korean strategic partnership and the provisional implementation of the EU-South Korea Free Trade Agreement (FTA) began. The second period is classified as a "disruption" period (July 2013 to June 2016), which contains the EU's multiple crises-for example, the migrant crisis, the Greek financial bailout, the Brexit referendum, and other possible following conflicts. The third period is classified as a "challenge" period when the COVID19 pandemic broke out and Brexit officially happened (finishing the transition period at the end of 2020).

Table 1. Data collection period classification and major events between the EU and South Korea.

\begin{tabular}{|c|c|c|}
\hline Classification & Duration & Major Events \\
\hline $\begin{array}{c}\text { Period } 1 \\
\text { (Expectation) }\end{array}$ & July 2010 June 2013 & $\begin{array}{l}\text { (October 2010) EU-South Korea Strategic } \\
\text { Partnership Launched } \\
\text { (July 2011) EU-South Korea Free Trade Agreement } \\
\text { Provisionally Entered into Force }\end{array}$ \\
\hline $\begin{array}{c}\text { Period } 2 \\
\text { (Disruption) }\end{array}$ & July 2013 June 2016 & $\begin{array}{l}\text { (2015) Europe's Migrant Crisis } \\
\text { (June 2015) Greek Bailout Referendum } \\
\text { (June 2016) Brexit Referendum }\end{array}$ \\
\hline $\begin{array}{c}\text { Period } 3 \\
\text { (Challenges) }\end{array}$ & July 2016 June 2020 & $\begin{array}{l}\text { (December 2019) COVID-19 } \\
\text { (January 2020) Brexit Day and the Beginning of } \\
\text { Transition Period }\end{array}$ \\
\hline
\end{tabular}

This study grouped six major South Korean newspapers into two groups (conservative and liberal) for comparative purposes. Conservative newspapers included The Chosun Ilbo, The Dong-A Ilbo, and JoongAng Daily, while the liberal newspapers were Hankook Ilbo, The Hankyoreh, and Kyunghyang Shinmun [8]. This sample of newspapers was chosen 
due to their representativeness in terms of their readerships, influence, and news market shares [35]. To establish a data archive for analysis, this study employed BigKinds (a big data archive for South Korean newspapers) [36] and UiPath (a web-scraping tool) [37] to implement data collection. The data archive consists of 36,400 new articles in total related to the EU (Table 2). In Periods 1 and 2, liberal newspapers (61.4\% in Period 1 and $58 \%$ in Period 2) produced more EU-related articles than conservative newspapers did (38.6\% in Period 1 and $42 \%$ in Period 2) (Table 2). However, in Period 3, conservative newspapers $(54.9 \%)$ had a higher percentage of EU-related articles than liberal newspapers did $(45.2 \%)$ (Table 2$)$.

Table 2. Data profile of collected articles.

\begin{tabular}{|c|c|c|c|c|c|c|c|}
\hline \multirow{2}{*}{ Political Orientation } & \multirow{2}{*}{ Newspapers } & \multicolumn{2}{|c|}{ Period 1} & \multicolumn{2}{|c|}{ Period 2} & \multicolumn{2}{|c|}{ Period 3} \\
\hline & & Number & Percentage & Number & Percentage & Number & Percentage \\
\hline \multirow{3}{*}{ Conservative } & The Chosun Ilbo & 1201 & $10.0 \%$ & 1045 & $11.2 \%$ & 2908 & $19.3 \%$ \\
\hline & The Dong- $A$ Ilbo & 2056 & $17.1 \%$ & 1422 & $15.3 \%$ & 2156 & $14.3 \%$ \\
\hline & JoongAng Daily & 1385 & $11.5 \%$ & 1447 & $15.5 \%$ & 3192 & $21.2 \%$ \\
\hline \multicolumn{2}{|c|}{ Sub-total } & 4642 & $38.6 \%$ & 3914 & $42.0 \%$ & 8256 & $54.8 \%$ \\
\hline \multirow{3}{*}{ Liberal } & Hankook Ilbo & 1658 & $13.8 \%$ & 1522 & $16.4 \%$ & 2550 & $16.9 \%$ \\
\hline & The Hankyoreh & 2960 & $24.6 \%$ & 1800 & $19.3 \%$ & 1887 & $12.5 \%$ \\
\hline & Kyunghyang Shinmun & 2769 & $23.0 \%$ & 2072 & $22.3 \%$ & 2370 & $15.7 \%$ \\
\hline \multicolumn{2}{|c|}{ Sub-total } & 7387 & $61.4 \%$ & 5394 & $58.0 \%$ & 6807 & $45.2 \%$ \\
\hline \multicolumn{2}{|c|}{ Total } & 12,029 & $100.0 \%$ & 9308 & $100 \%$ & 15,063 & $100.0 \%$ \\
\hline
\end{tabular}

Figure 1 presents the quarterly distribution of EU-related articles in South Korean major newspapers during Period 1. Here, Q1 means the months January to March, Q2 means April to June, Q3 means July to September, and Q4 means October to December. The peak time periods in Figure 1 were Q2 and Q4 in 2011. In Q2 2011, the EU-Korea FTA was provisionally applied, and this might have led to the increase in the number of EU-related news articles. In Q4 2011, the debt crises of Italy and Spain presented the main agenda of our data set; therefore, Europe's debt crisis and the accompanying fear about the possible impact on the South Korean economy was the possible trigger point of the sudden increase in the number of EU-related news items. These trigger points imply that South Korean newspapers and their readers would have expectations of the EU in terms of increasing their national wealth by access to the biggest market in the world.

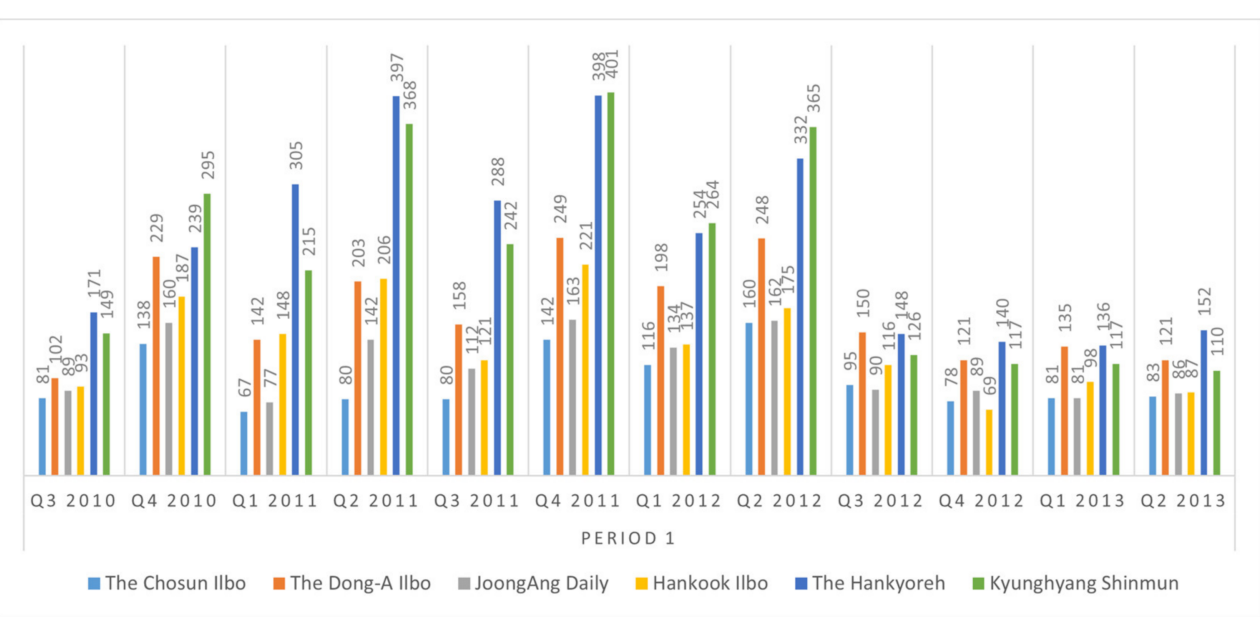

Figure 1. Quarterly distribution of EU articles in South Korean major newspapers (Period 1). 
Figure 2 presents quarterly distributions of EU-related articles in South Korean major newspapers during Period 2. The peak here was the second quarter of 2016. The primary reason for this increase was the Brexit referendum in June 2016. When the results of the referendum were reported, the reality of the Brexit outcome caused real anxiety among the Korean public due to the possible crisis arising from the uncertain future of the European common market [21]. This period was recorded as a period of disruption when the EU faced multiple crises, which were the turning point in changing Korean perceptions of the EU. In particular, they increased the negative image of the EU among the South Korean news media [21,38]. Based on the trend in Period 2, the prominent keywords in the collected articles were saturated with those related to the Union's crises and their possible impact on South Korea.

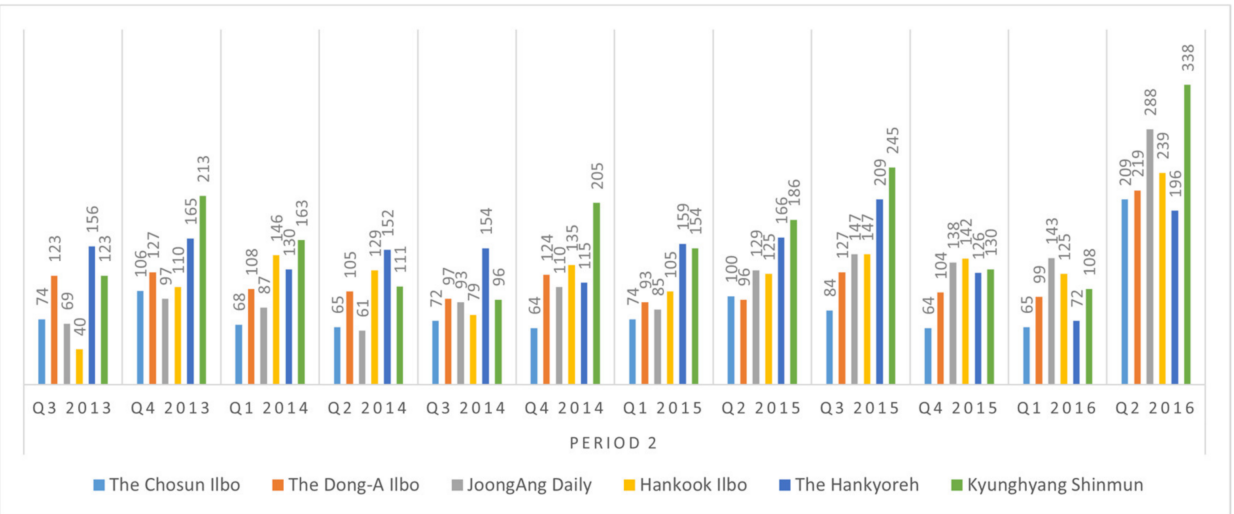

Figure 2. Quarterly distribution of EU articles in South Korean major newspapers (Period 2).

Figure 3 presents the quarterly distribution of EU-related articles during Period 3. Based on the average number of articles produced, there are two peak points (Q3 2016 and Q1 2019) needing further explanation. Following on from the previous period, the third quarter of 2016 witnessed the news media covering the possible impacts of Brexit on South Korea and its economy and trade with the EU and the UK. During the first quarter of 2019, the EU and UK conducted successful negotiations regarding the UK's exit from the EU on 29 March 2019, two years after triggering Article 50 of the Lisbon Treaty (the legal mechanism for EU member states to leave the European Union).

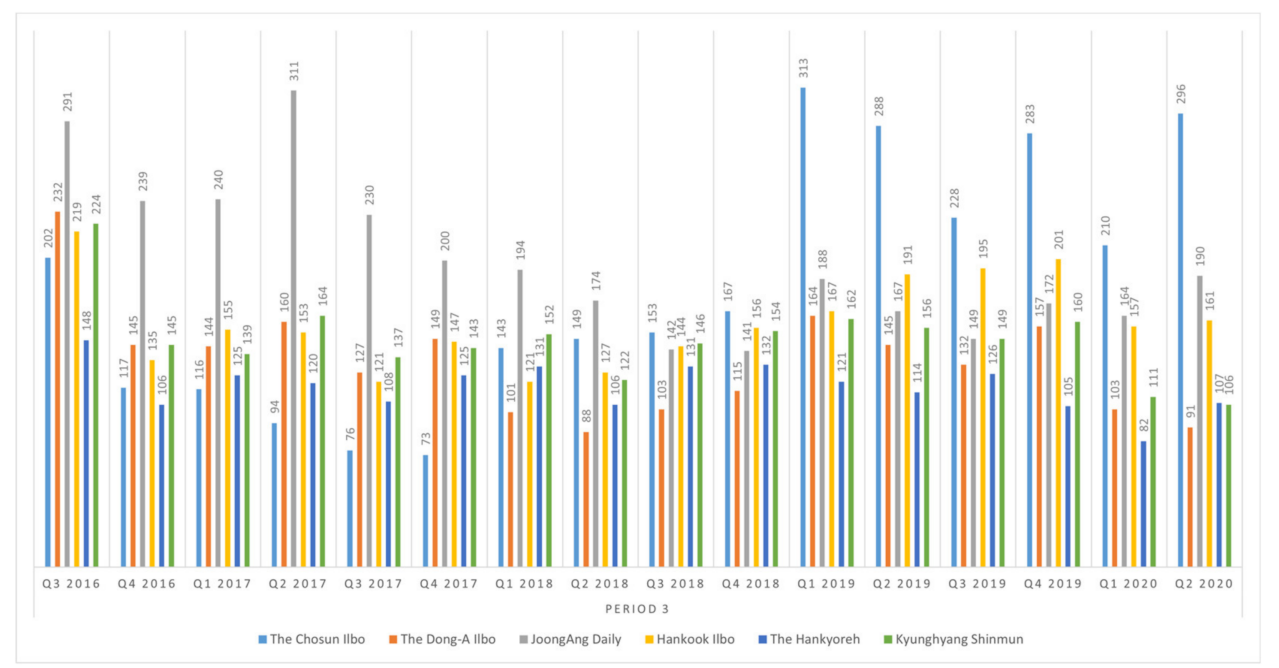

Figure 3. Quarterly distribution of EU articles in South Korean major newspapers (Period 3).

Reviewing the quarterly distribution of EU articles in South Korean major newspapers, there are three points to be re-considered. First, the EU's crises were the trigger points 
for boosting the number of EU-related news articles (Period 1: Eurozone financial crisis; Period 2: Brexit negotiation; and Period 3: Brexit day). Second, Korean perceptions of the EU have been changed from positive expectations to crisis awareness. In the first period, South Koreans had expectations of the EU because of their substantial co-operation (EU-Korea FTA and strategic partnership). In the second period, the South Korean media raised concerns about the possible impacts of the EU's crises. In the third, the South Korean median representation of the EU has become a case of crisis communication practices. According to Huang, $\mathrm{Wu}$, and Cheng, crisis communication refers to "verbal and nonverbal responses that organisations use to address a crisis" [39] (p. 202). Although more thorough investigations are necessary, South Korean newspapers' increase in coverage of EU affairs is considered a call for the management of upcoming crises caused by the union's uncertainty.

\subsection{Methods}

\subsubsection{Semantic Network Analysis}

Semantic network analysis is a quantitative methodology that extracts knowledge representations from, text by first denoting the content of messages in the text as a network of objects [40]. Constructing a semantic model from word collocation is the main objective of this methodology [41]. Software is usually employed to tokenise different words in sentences and to filter semantically irrelevant words [42]. Subsequently, network representation is visualised in the format of weighted graphs containing semantic mappings. A weighted graph consists of nodes (the words) and edges (the word relations) [43]. Weights are calculated by applying quantitative measures to affect the layout of the network [43] (p. 7). Semantic network analysis is useful for data representation and relational structure detection [43].

Semantic network analysis enables more reliable coding without expensive and laborious human coders [40]. It is a systematic analytic method that make the data gathered suitable for answering research questions [40]. In semantic network analysis, the network representation is queried to answer the research questions given [40]. However, this approach is challenging in terms of extracting the network of relations due to the complexity of coding [40]. Van Atteveldt claimed that the results from measured objects are closer to the text than in manual thematic content analysis, because semantic network analysis can narrow the semantic gap between words and meaning [40]. There are several advantages to this approach. First, it is convenient for collecting and analysing large amounts of data using computer software [44]. Second, it enables diverse research approaches from diverse academic backgrounds [44]. In other words, it is open to multidisciplinary studies. Third, it has greater cognitive adequacy compared to logic-based formalism [44]. Finally, it has greater logical expression via the visualisation of semantic networks [44].

Semantic Network Analysis consists of four steps. The first step is to measure the frequency and weight of the words and word-pairs in the collected texts. For the collection of the news text, this study employed BigKinds (Korean big data platform for major news media outlets) and UiPath (automated data collection software). The results are presented in tabular format. The second step is the tokenisation and filtering process achieved using the analytic software. The third step is the visualisation of the semantic networks extracted from the text. In this study, the NodeXL software was used for the tokenisation, filtering, and visualisation processes. NodeXL is a programme developed by the Social Media Research Foundation and is attached as an add-in to Microsoft Excel. It is useful in terms of convenient data analysis and visualisation [45]. The results of the visualisation of the semantic network are presented in the form of semantic mapping. The final step in this process is to draw social implications from the results [39]. The data analysis of this research was mostly conducted by quantitative approaches using the appropriate software. They were more convenient and accurate in terms of data collection, analysis, and visualisation than qualitative approaches. However, they were not still sufficient in terms of the further in-depth interpretation of the data we prepared. This process can be achieved by qualitative 
media content analysis and other possible relevant data such as public opinion surveys measuring the impact of the news media.

\subsubsection{Framing Analysis}

For the qualitative media content analysis, this study implemented the framing analysis suggested by Semetko and Valkenburg [14]. Framing is a term coined by Erving Goffman's study Frame Analysis. Framing is the "schemata of interpretation" that enables individuals "to locate, perceive, identify and label" information [46] (p. 21). Gitlin applied the concept of framing to explore media social interactions. He defined the frames as a process of "persistent selection, emphasis and exclusion" [47] (p. 7). Gamson and Modigliani defined the frames as a "central organising idea or story line that provides meaning" [48] (p. 143). Extending the work of Gamson and Modigliani [49], Pan and Kosicki conceptualise framings as a central theme or organising idea underpinning every news story [50]. Entman claims that framing emerges from selection and salience [51]. He adds: "to frame is to select some aspects of a perceived reality and make them more salient in a communicating text, in such a way as to promote a particular problem definition, causal interpretation, moral evaluation, and/or treatment recommendation" [51] (p. 52). Framing analysis is compatible with semantic network analysis in terms of detecting salient themes from word/word-pair frequencies and weight. Ultimately, semantic networks can demonstrate the blueprint of framings embedded in the media texts.

For an analytic model, Semetko and Valkenburg suggested five experimental framing conditions based on the empirical studies on framings: conflict frame, human interest frame, economic consequences frame, morality frame, and responsibility frame [14]. First, a conflict frame is caused when there is an emphasis on conflict between opponents and proponents in attaining the interest of the audiences [14]. Examples of this form include presidential elections [50] or inducing public mistrust of political leaders [52]. The human interest frame refers to "an effort to personalise, dramatise, or emotionalise the news, in order to capture and retain audience interests" [14] (p. 96). The economic consequences frame results from the main story in news articles making the public think about their economic consequences [14]. Neuman et al. suggest this framing is the most common one in news media [52]. For instance, the news media release news items about the economic impact of global issues in the society where the audience is located. The morality frame reports issues or problems "in the context of [ ... ] moral prescriptions" [14] (p. 96). The media uses this framing device to address sensitive social issues by asking questions or leaving the agenda to the audience. Due to issues of objectivity, journalists use references to establish morality frames [41], which seem to have an impact as they influence the social norms embedded in the minds of the audience. Finally, the responsibility frame occurs when someone makes other individuals or groups (who are responsible for the cause) a solution for certain issues (usually social problems) [14]. Examples can be found from Iyengar's study on television news, in which the audience are induced or encouraged to individually answer questions about social problems such as poverty [53]. Based on Semetko and Valkenburg's experimental framings, this study explores the relevant framings embedded in semantic network mapping to decipher inherent meaning. Since the text is unstructured data, the interpretation of the data collected, extracted, and analysed seems to be essential. To avoid the ad hoc interpretation of the data, this study employs media frames that determine their preliminary arrangements. Subsequently, we approach which types of media framings were salient in the EU coverage in the Korean news media. For instance, when Korean media were inclined to project conflict frames in covering EU affairs, we can interpret that the Korean media tend to show the negative perceptions of the EU. We can also explore the Korean media's motivation to cover negative issues about the EU by looking at the issues attached to the conflict frames.

After the interpretation of the results, this study attempts to measure readers' perceived impact of the media framing. In this regard, this study formulated survey questions and conducted a public opinion survey supported by Embrain Research Company. The 
number of participating respondents was 1000 and the period was the third week of August 2020 (19-24 August 2020). The results will be analysed in the discussion section.

\section{Results}

The first part of the data set consists of the top ten words and word groups with the greatest weight values measured by the analytic software (NodeXL). The weight of the words indicates the degree of association links between nodes [54]. Associations with higher values refer to their salience- "a measure of how often the word occurs compared to other words" within the discourse [54] (p. 93). Lehmann exemplified the case of the Richard Nixon metaphor: "Richard Nixon is the submarine of foreign policy" [55] (p. 28). From this metaphor, the descriptions of Nixon will become salient by utilising the persuasive power of metaphors to trigger the audience's cognition about certain objects. From NodeXL, this study calculated the salient weights of words and word-pairs. Table 3 shows the top 10 words according to their weight values.

Table 3. Top ten words with the greatest weight values.

\begin{tabular}{|c|c|c|c|c|c|c|c|c|c|c|c|c|}
\hline \multirow[b]{3}{*}{ Rank } & \multicolumn{4}{|c|}{$\begin{array}{c}\text { Period } 1 \\
\text { (July 2010 June 2013) }\end{array}$} & \multicolumn{4}{|c|}{$\begin{array}{c}\text { Period 2 } \\
\text { (July 2013 June 2016) }\end{array}$} & \multicolumn{4}{|c|}{$\begin{array}{c}\text { Period } 3 \\
\text { (July 2016 June 2020) }\end{array}$} \\
\hline & \multicolumn{2}{|c|}{ Conservative } & \multicolumn{2}{|c|}{ Liberal } & \multicolumn{2}{|c|}{ Conservative } & \multicolumn{2}{|c|}{ Liberal } & \multicolumn{2}{|c|}{ Conservative } & \multicolumn{2}{|c|}{ Liberal } \\
\hline & Word & Value & Word & Value & Word & Value & Word & Value & Word & Value & Word & Value \\
\hline 1 & EU & 0.011 & FTA & 0.014 & EU & 0.009 & EU & 0.010 & $\mathrm{EU}$ & 0.010 & Brexit & 0.011 \\
\hline 2 & FTA & 0.010 & EU & 0.014 & Europe & 0.007 & Greece & 0.010 & Trump & 0.009 & EU & 0.010 \\
\hline 3 & Europe & 0.008 & Korea & 0.010 & US & 0.007 & Brexit & 0.009 & Brexit & 0.008 & Trump & 0.009 \\
\hline 4 & Greece & 0.007 & Europe & 0.009 & Greece & 0.006 & Europe & 0.009 & US & 0.008 & UK & 0.007 \\
\hline 5 & Korea & 0.007 & US & 0.009 & Korea & 0.006 & Refugee & 0.007 & Europe & 0.007 & Europe & 0.007 \\
\hline 6 & US & 0.005 & Euro-zone & 0.008 & Brexit & 0.005 & Korea & 0.007 & UK & 0.007 & US & 0.007 \\
\hline 7 & Economy & 0.005 & Iran & 0.006 & Global & 0.005 & US & 0.006 & Korea & 0.007 & Korea & 0.007 \\
\hline 8 & Euro-zone & 0.005 & Crisis & 0.006 & Economy & 0.005 & China & 0.005 & China & 0.007 & Export & 0.006 \\
\hline 9 & Iran & 0.005 & China & 0.005 & China & 0.004 & Germany & 0.005 & Export & 0.005 & $\begin{array}{l}\text { Prime } \\
\text { Minister }\end{array}$ & 0.006 \\
\hline 10 & China & 0.004 & Bailout & 0.005 & UK & 0.004 & Economy & 0.005 & Economy & 0.004 & President & 0.005 \\
\hline
\end{tabular}

Throughout the whole period, the data yielded similar results for both conservative and liberal newspapers. During Period 1, keywords related to the economy (such as FTA, Eurozone, economy, and bailout) and significant global counterparts (such as the US, China, and Iran) were salient for the EU and South Korea. During Period 2, crisis-related keywords such as Brexit, Greece, and Germany gained visibility in the South Korean media discourse, alongside keywords related to the major global actors for both parties. During Period 3, crisis-related keywords related to the EU's internal and external challenges (such as Brexit, UK, Trump, US, and China) became dominant in the media discourse. From the results shown in Table 3, the EU's image has shifted from being a global economic powerhouse to that of a global actor facing multiple challenges saturated with crises. Table 4 indicates the top 10 word-pairs according to their weight values. 
Table 4. Top ten word-pairs with the greatest weight values.

\begin{tabular}{|c|c|c|c|c|c|c|c|c|c|c|c|c|}
\hline \multirow[b]{3}{*}{ Rank } & \multicolumn{4}{|c|}{$\begin{array}{c}\text { Period } 1 \\
\text { (July 2010 June 2013) }\end{array}$} & \multicolumn{4}{|c|}{$\begin{array}{c}\text { Period } 2 \\
\text { (July 2013 June 2016) }\end{array}$} & \multicolumn{4}{|c|}{$\begin{array}{c}\text { Period } 3 \\
\text { (July 2016 June 2020) }\end{array}$} \\
\hline & \multicolumn{2}{|c|}{ Conservative } & \multicolumn{2}{|c|}{ Liberal } & \multicolumn{2}{|c|}{ Conservative } & \multicolumn{2}{|l|}{ Liberal } & \multicolumn{2}{|l|}{ Conservative } & \multicolumn{2}{|l|}{ Liberal } \\
\hline & Word Pair & Value & Word Pair & Value & Word Pair & Value & Word Pair & Value & Word Pair & Value & Word Pair & Value \\
\hline 1 & EU-FTA & 0.004 & EU-Korea & 0.008 & EU-Exit & 0.002 & Korea-China & 0.002 & May-Prime Minister & 0.002 & Moon-President & 0.003 \\
\hline 2 & Korea-FTA & 0.004 & EU-FTA & 0.007 & Park-President & 0.001 & Park-President & 0.002 & US-China & 0.001 & US-China & 0.002 \\
\hline 3 & Korea/US-FTA & 0.002 & Korea-US & 0.005 & US-EU & 0.001 & China-FTA & 0.002 & UK-May & 0.001 & May-Prime Minister & 0.002 \\
\hline 4 & Korea-US & 0.002 & US-FTA & 0.004 & Korea-China & 0.001 & Greece-Bailout & 0.001 & US-China & 0.001 & ILO-Core Negotiations & 0.001 \\
\hline 5 & Korea-EU & 0.002 & $\begin{array}{c}\text { Eurozone } \\
- \\
\text { Crisis }\end{array}$ & 0.002 & Sanctions-Lift & 0.001 & Brexit-aftereffect & 0.001 & French-Presidential Election & 0.001 & Brexit-Negotiation & 0.001 \\
\hline 6 & Korea-China & 0.002 & Korea-China & 0.002 & EU-Stay & 0.001 & Iran-Nuclear Negotiation & 0.001 & Global-Economy & 0.001 & French-Presidential Election & 0.001 \\
\hline 7 & FTA-Operation & 0.001 & FTA-Ratification & 0.001 & Korea-China & 0.001 & FTA-Operation & 0.001 & Brexit-Negotiation & 0.001 & No-Deal & 0.001 \\
\hline 8 & Europe-Crisis & 0.001 & $\begin{array}{c}\text { Translation } \\
- \\
\text { Error }\end{array}$ & 0.001 & US-China & 0.001 & Additional-Sanction & 0.001 & UK-Brexit & 0.001 & UK-Brexit & 0.001 \\
\hline 9 & China-Japan & 0.001 & $\begin{array}{l}\text { Eurozone- } \\
\text { Bailout }\end{array}$ & 0.001 & UK-EU & 0.001 & $\begin{array}{l}\text { Mediterranean } \\
\text {-Refugee }\end{array}$ & 0.001 & No Deal-Brexit & 0.001 & Korea-EU & 0.001 \\
\hline 10 & US-China & 0.001 & $\begin{array}{c}\text { FTA- } \\
\text { re-negotiation }\end{array}$ & 0.001 & $\begin{array}{c}\text { Korea-EU } \\
(0.001)\end{array}$ & 0.001 & US-Russia & 0.001 & UK-Exit & 0.001 & Tariff-Levy & 0.001 \\
\hline
\end{tabular}


In the first period, the most salient word-pairs depict Korea's FTA and its processes with the EU and other global partners. In liberal newspapers, the word-pairs regarding Eurozone issues (such as crisis and bailout) gained visibility in the texts. During the second period, the salient word-pairs of conservative and liberal newspapers turned out to be different. In the conservative newspapers, salient word-pairs mainly addressed Brexit. In the liberal newspapers, the salient word-pairs related to the EU's multiple internal conflicts (such as the post-Brexit effect, the Greece-bailout, and Mediterranean refugees) and external challenges (such as the US-Russia and Iran nuclear negotiations). In the final period, the most salient word-pairs refer to Brexit in both liberal and conservative newspapers.

Figures 4-6 visualise the networks for the keywords as a form of semantic network analysis. This study attempts to show the framing evolutions over the three periods. Figure 4 indicates the semantic networks for Korean conservative and liberal newspapers.

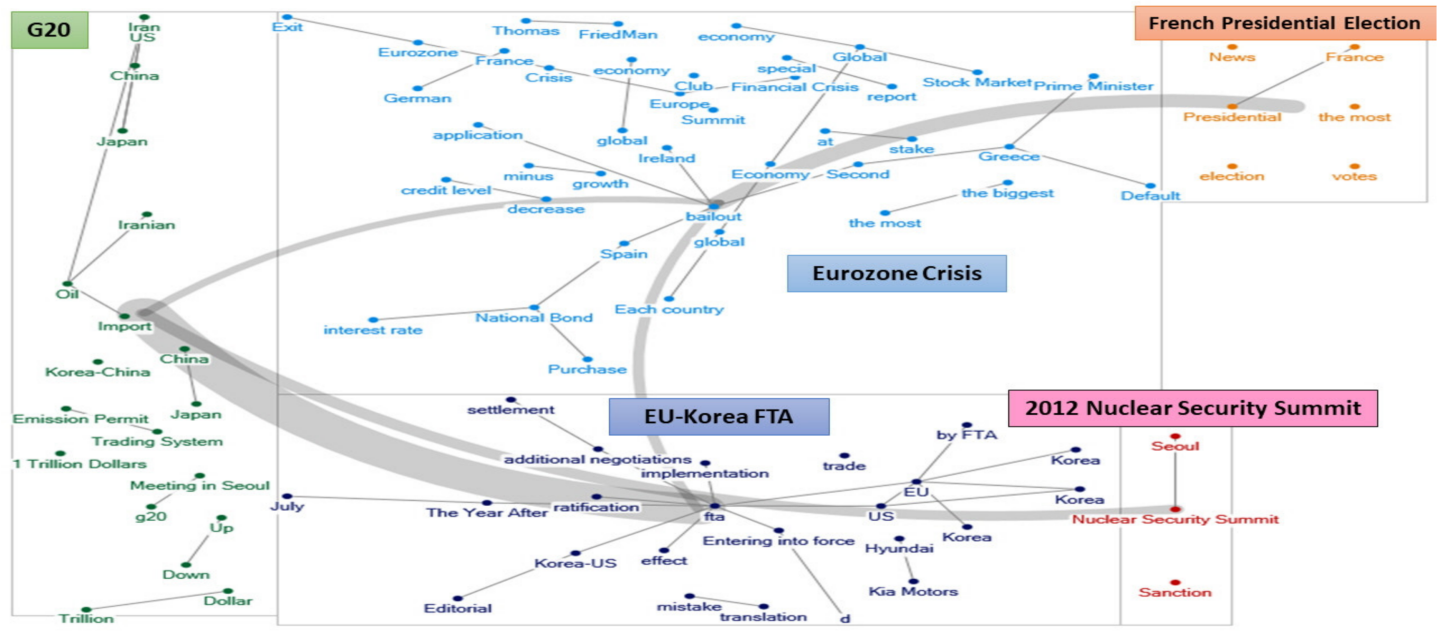

(a)

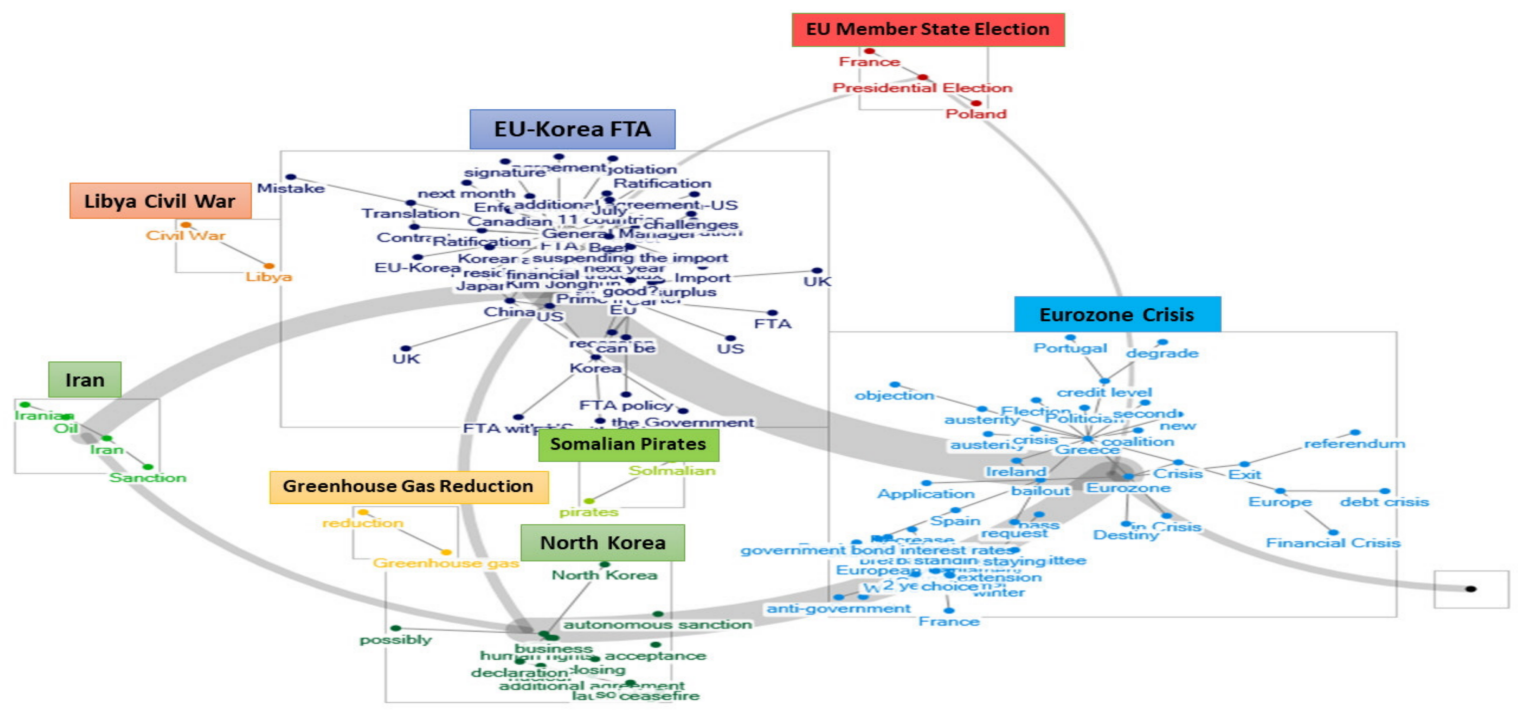

(b)

Figure 4. Semantic network mapping of conservative newspapers (a) and liberal newspapers (b) for Period 1. 


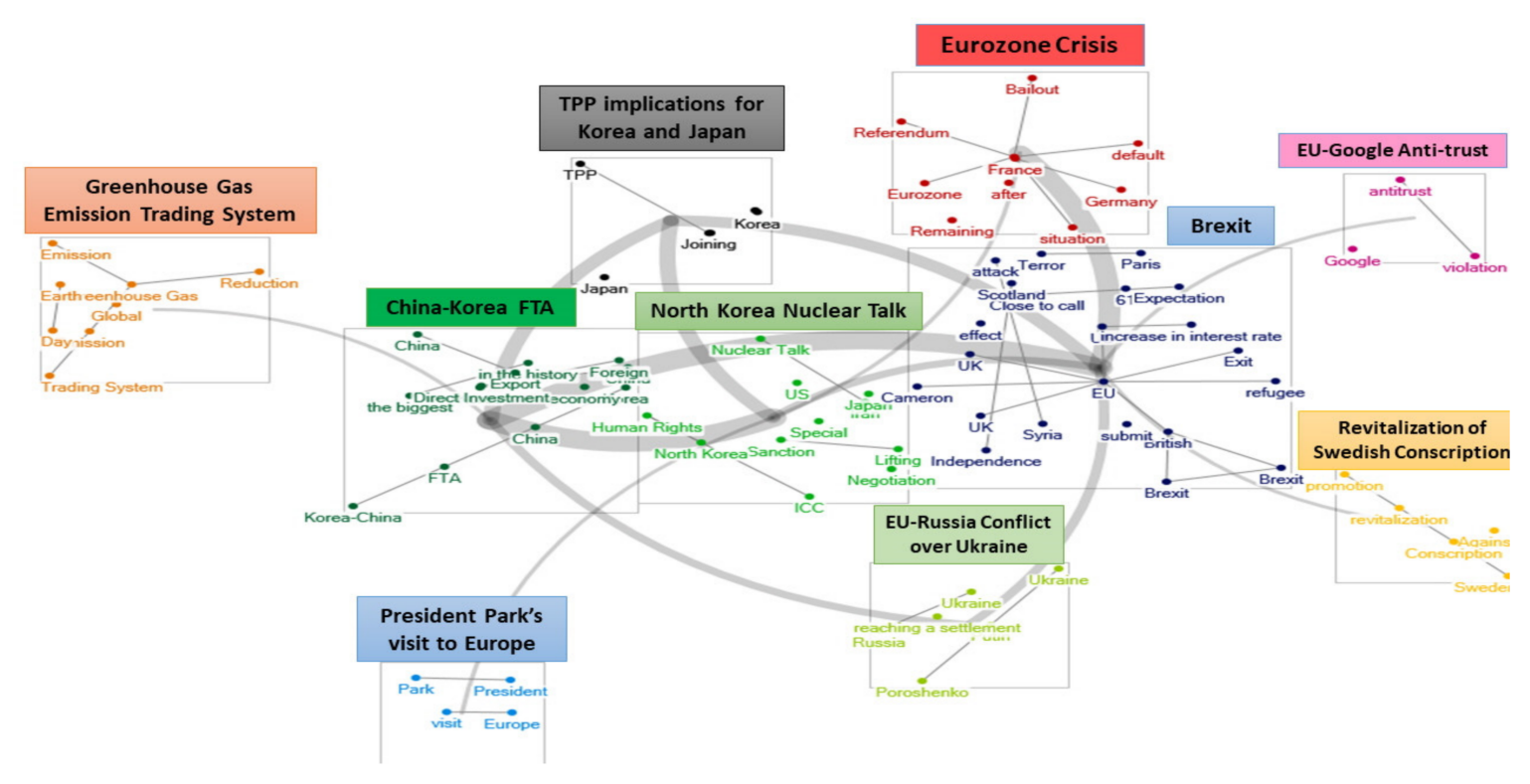

(a)

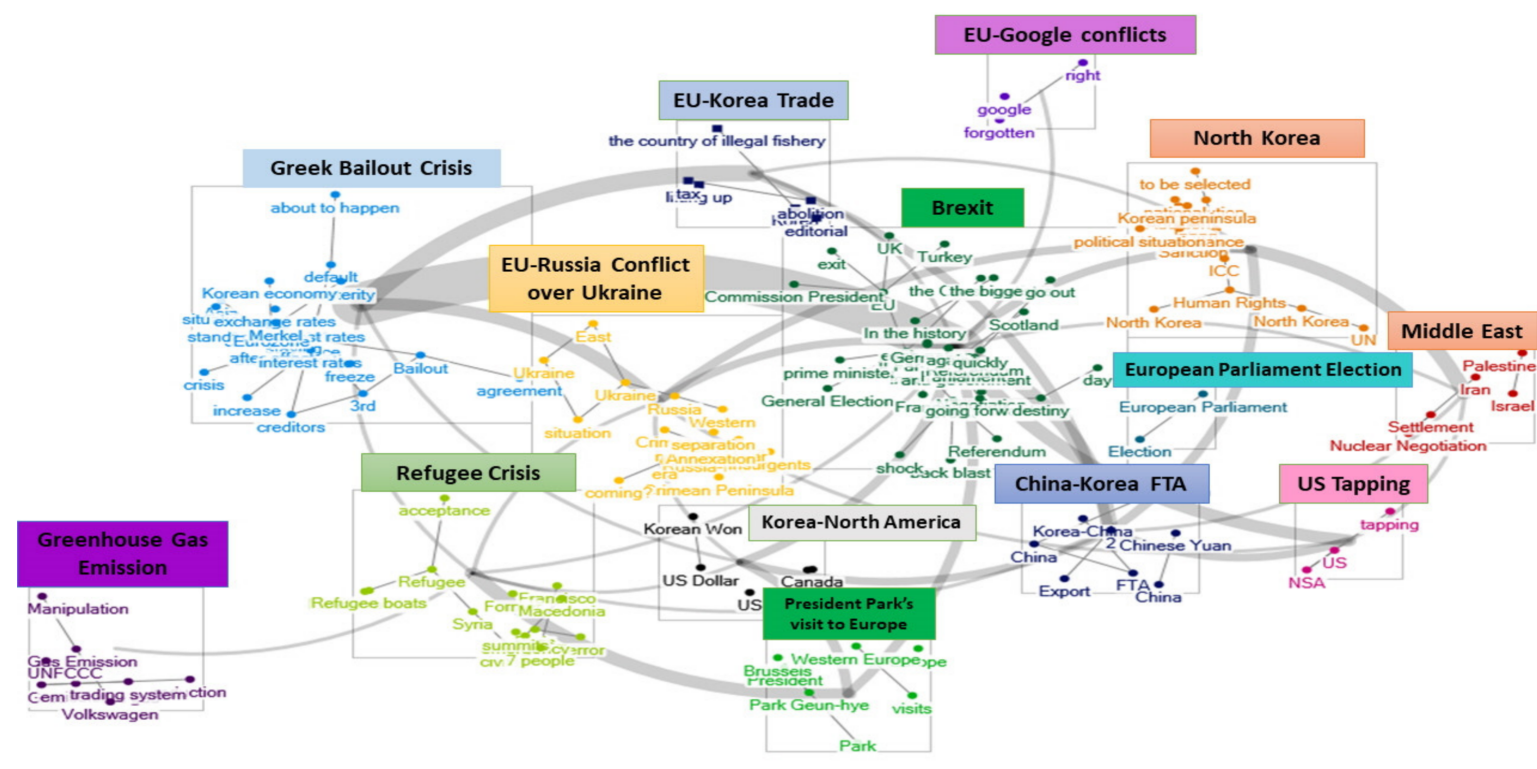

(b)

Figure 5. Semantic network mapping of conservative newspapers (a) and liberal newspapers (b) for Period 2. 


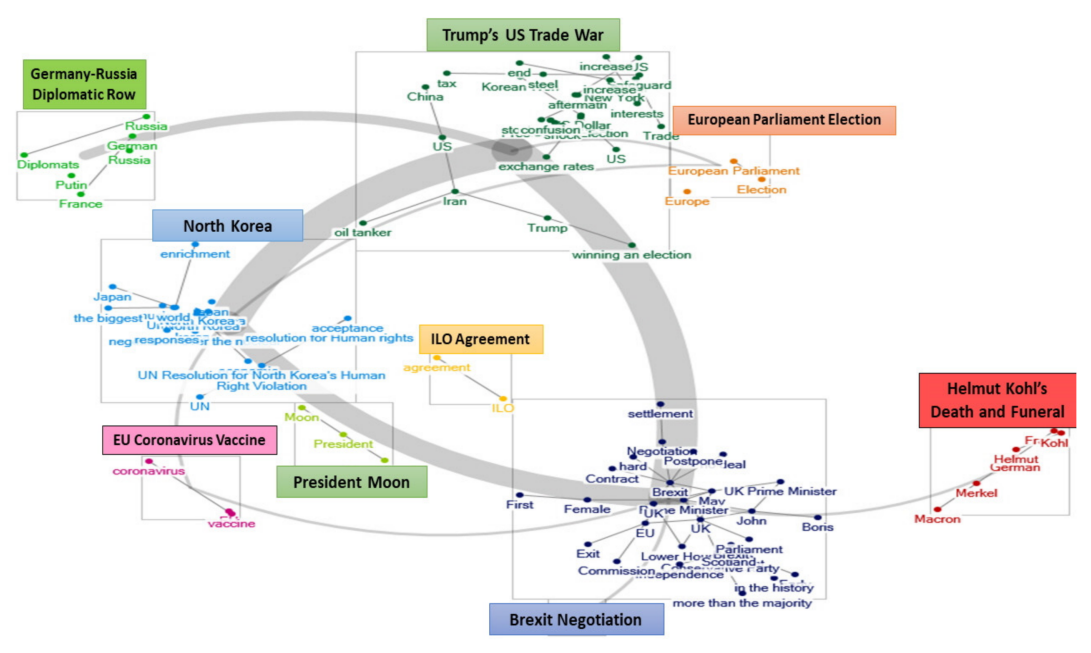

(a)

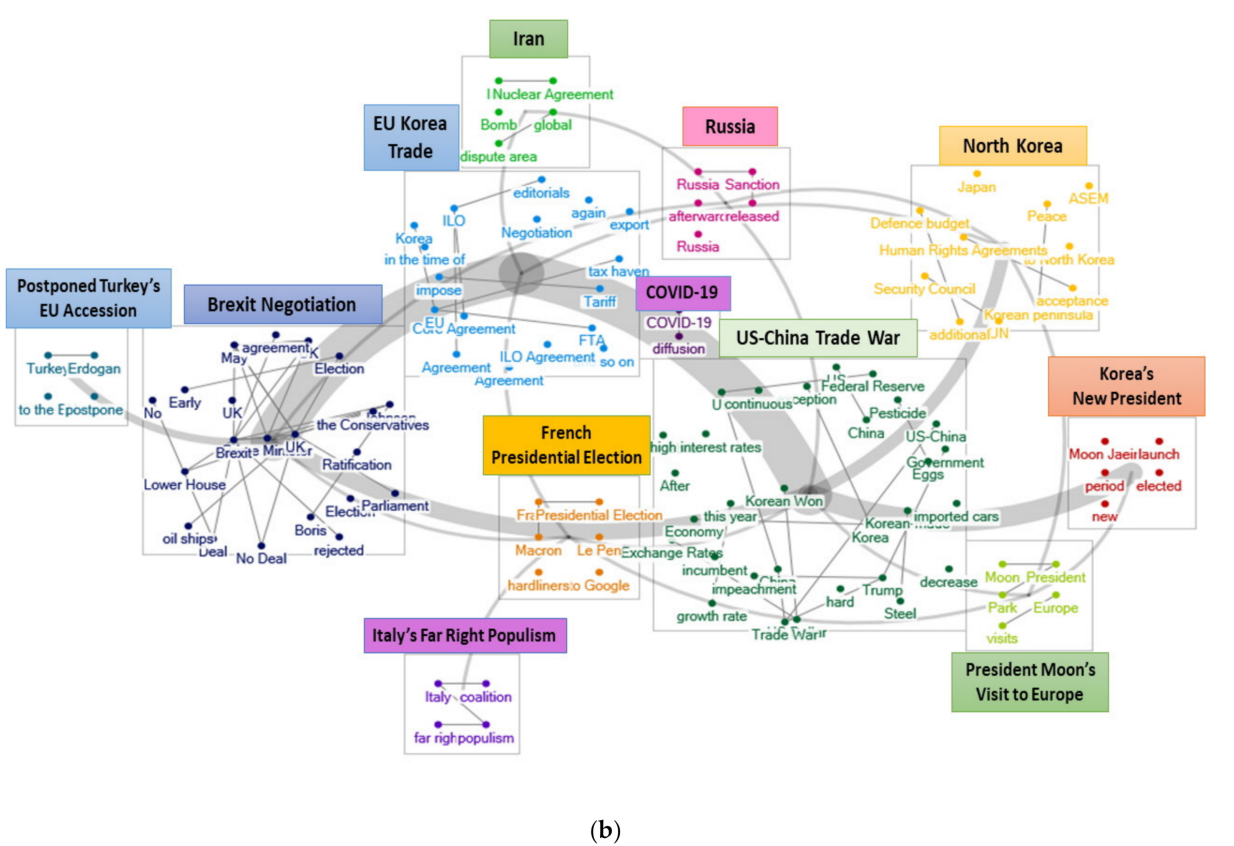

Figure 6. Semantic network mapping of conservative newspapers (a) and liberal newspapers (b) for Period 3.

In Figure 4, the framings in both conservative and liberal newspapers were either economic consequences or conflict frames. Conservative newspapers mainly contained economic consequences frames (such as the EU-Korea FTA and the G20), while conflict frames such as the 2012 Nuclear Security Summit were the main framings likely to emphasise the achievements of the Korean government and its ruling (conservative) party during the first period (July 2010 to June 2013). The conservative media used more economic consequences frames to attract readers' attention. Among the liberal media, the EU-Korea FTA was also the main economic consequences frame and the Eurozone crisis was the main conflict framing. The liberal media also introduced a more diverse range of conflict frames by introducing regional issues (such as the Libya Civil War, Iran, and Somalian pirates), and global issues (such as North Korea and greenhouse gas reduction). The liberal media were inclined to use conflict frames to capture audiences' interest. Moving on to the second period (July 2013 to June 2016), both types of news media presented more diversified sets of framings, and the results are summarised in Figure 5 below. 
In Figure 5, both conservative and liberal newspapers present similar semantic network maps in terms of the frames identified (conflict, economic consequences, and human interest). For the conflict frames, conservative newspapers covered issues concerning the EU's crises (Eurozone issues and Brexit) and regional security issues for both the EU (EU-Russia conflict over Ukraine) and South Korea (North Korea's missile test). Liberal newspapers introduced more diversified frames introducing the EU's crises (Brexit and refugee crisis), its regional challenges for both the EU (EU-Russia conflict over Ukraine, Iran's nuclear talks) and South Korea (nuclear talk with North Korea), and global challenges (the US tapping of French and German governments). The economic consequences frames in conservative newspapers mainly addressed the EU's performance in the global economy (such as greenhouse gas emissions, trading systems, and EU-Google anti-trust), and the post-Brexit consequences (such as the UK's participation in the Trans-Pacific Partnership after Brexit), which implies that the Brexit frame can also be one of the global economic consequences frames. Liberal newspapers addressed the main themes about the EU's domestic issues such as the Greek bailout crisis, the union's global economic contributions (EU-Google antitrust conflict), and its further global impacts (Korea's FTA with China and the US). The human interest frames in both conservative and liberal newspapers presented President Park Geun-hye's visits to Europe as their common framing. Apart from this frame, the conservative media were inclined toward addressing security issues of the EU member states (the revitalisation of Swedish conscription) and the liberal media were more inclined to address the EU's political main event (European Parliament elections in 2014). Figure 6 illustrates the frame mapping for conservative and liberal media during the third period.

In Figure 6, both conservative and liberal media projected three frames: conflict, economic consequences, and human interests. However, both types of media featured slightly different elements in these frames. For the conflict frames, both covered Brexit negotiations as a main theme and COVID-19 as a common theme with great timeliness. The conservative media's conflict frames addressed the disruptions in Germany (Germany-Russia diplomatic row) and the liberal media's conflict frames addressed the EU's regional challenges (Turkey's EU accession, Iran's nuclear talks, and the EU's sanctions over Russia) and global disruption (the EU's role over North Korean nuclear weapons and human rights promotion). For the economic consequences frames, both types of media covered the effect of the EU-Korea trade issue over International Labour Organisation (ILO) ratification and the "Trump" factor on global trade (the EU's position in Trump's trade war with China) as major frames. In the human interest frames, both media types commonly addressed President Moon's visits to Europe; however, the liberal newspapers focussed more on Korea's new president after the impeachment of President Park in March 2017. They also presented events that happened in the EU, such as Helmut Kohl's death and funeral in the conservative media and the French Presidential election for the liberal media.

Over the last ten years, both types of newspapers addressed three main framings for conflict, economic consequences, and human interest. Although there were some changes in their subordinate themes under these framings, there were no notable differences between conservative and liberal newspapers in reporting EU issues. In the conflict frame, Brexit was clearly the predominant theme in the news texts collected. In the economic consequences frame, Eurozone issues was the first predominant theme during Period 1, although there was a shift toward EU-Korea trade issues after the implementation of the EU-Korea FTA. In light of the "Trump" factors, Korea's trade with the EU gained visibility in the news media. In the human interest frames, both newspapers were inclined toward covering EU-Korean bilateral interactions (such as the Korean president's visits to Europe) and events within the EU (elections and leadership change). In addressing the EU issues, this study could not find any responsibility or moral frames. It seems to be possible to say that the news reporters from both camps did not consider that the EU issues would influence Korean domestic politics and that these issues would therefore not be of interest to the Korean general public. 


\section{Discussion}

Based on the previous analysis, we would like to address two key points. First, EU news volumes have fluctuated over different periods. While more than 12,000 news articles were reported in Period 1, this volume reduced to approximately 9300 in Period 2. It then increased again to 15,000 in the final period. In Periods 1 and 2, liberal newspapers were more active in reporting EU news (see Table 2), and in Period 3 conservative newspapers delivered more EU news than liberal ones (see Table 2). It seems that this fluctuation reflects the Korean media's attention to EU affairs. Recalling the results from Table 4, during Period 1 the salient word-pairs show that Korean newspapers paid significant attention to Korea's expectation from having an FTA with the EU and possible synergy with other global powers (such as the US and China). In the subsequent period, the Korean media's attention diminished during the initial stage of the EU's multiple crises. During Period 3, Korean newspaper attention shifted focus onto Brexit. The results show that Korean journalists and news editors perceive Brexit as the most significant crisis of the union. Coombs pointed out that a crisis can create threats implying potential damage to the organisation [56]. Subsequently, he suggested that there are three types of threats that can emerge from the crisis: public safety, financial loss, and reputation loss [56]. The Korean news media coverage of Brexit has been undertaken because of the risk of potential economic impacts on the Korean economy in terms of potential challenges to the EU-Korea FTA [21]. Coombs suggested that there are three stages of crisis communication [56]. First, the pre-crisis stage mainly focuses on prevention and possible preparation for the crisis [56]. The second, the crisis response stage, is concerned with warnings about prompt and appropriate responses to the crises raised [21]. Finally, the post-crisis stage refers to seeking effective measures to deal with subsequent crises and possible commitments to providing follow-up information [56]. These results imply that Korean newspapers are at the first stage of crisis communication (the pre-crisis phase).

Second, despite the fluctuation in volume over periods, liberal newspapers tended to report EU news with more variety in themes. Liberal newspapers presented more issues that were not covered by conservative ones. Some examples included the Libyan civil war and Somalian pirates (Period 1), the Syrian refugee influx to Europe (Period 2), the postponement of Turkey's EU accession negotiation, the emergence of far-right populism in Italy, and the French presidential election in 2017 (Period 3). Such diversification can be observed in Figures 4-6. What was commonly observed from both conservative and liberal newspapers, however, was the fact that South Korean newspapers are likely to focus on the "crisis" in the EU per se in dealing with EU news. Such tendency resulted in a "lack" of morality and responsibility frames in South Korea's EU news of the five experimental framing conditions suggested by Semetko and Valkenburg [14]. This implies that Korean newspapers tended to select news based on the "fact" rather than the "value".

This was reflected among Korean public perceptions. In this regard, the authors commissioned the Embrain Research Company to conduct public opinion survey for the period 19-24 August 2020. According to the results, 1063 Korean respondents across the nation replied they have a neutral perception of the EU-Korea relationship. To the question "which of the following best describes South Korea's relationship with the EU?", almost two thirds of respondents (59.1\%) replied "Neither good nor bad". The second choice was "Rather good" $(26.5 \%)$, and as many as $6.5 \%$ answered "Rather bad". The dominant perception of the bilateral relationship was "Neither good nor bad" (Figure 7). It seems that the South Korean public perceive that the EU's crises are not likely to worsen the bilateral relations. 


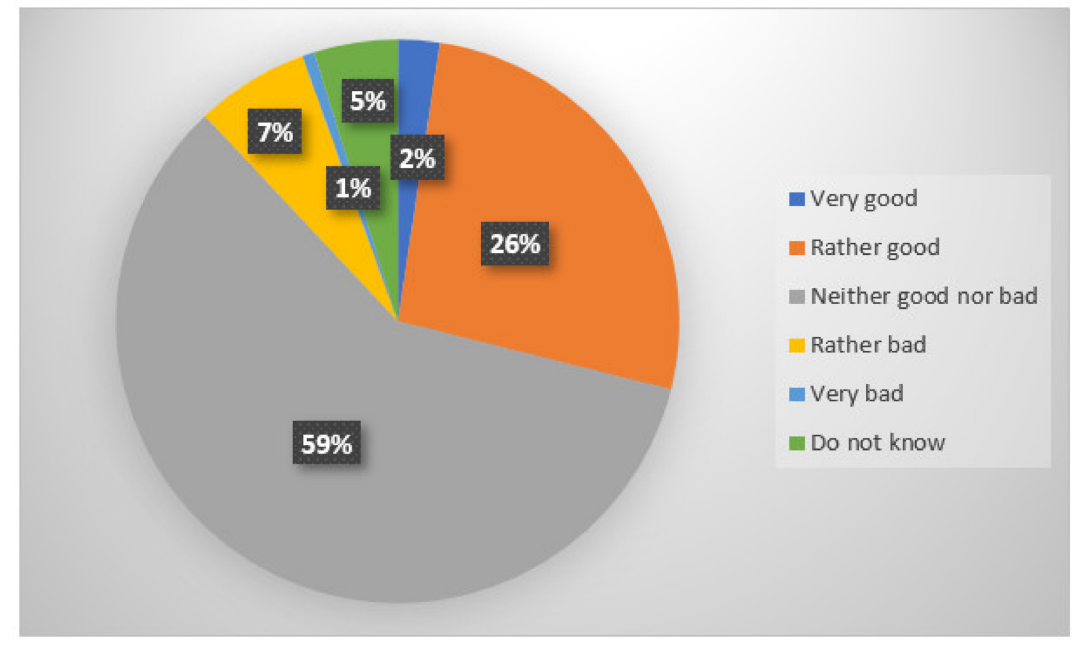

Figure 7. Which of the following best describes South Korea's relationship with the EU?

To the next question: "Do you think you know the EU well?", almost half of the respondents (48.1\%) said "No, and I want to know more". Slightly less than a quarter $(23.1 \%)$ said "Yes, but I want to know more". It thus seems that the EU is still prominent in the minds of the Korean public (Figure 8). This implies that the EU provokes the Korean public's curiosity. However, there are not enough good sources of information for the Korean public to enhance their understanding of the EU.

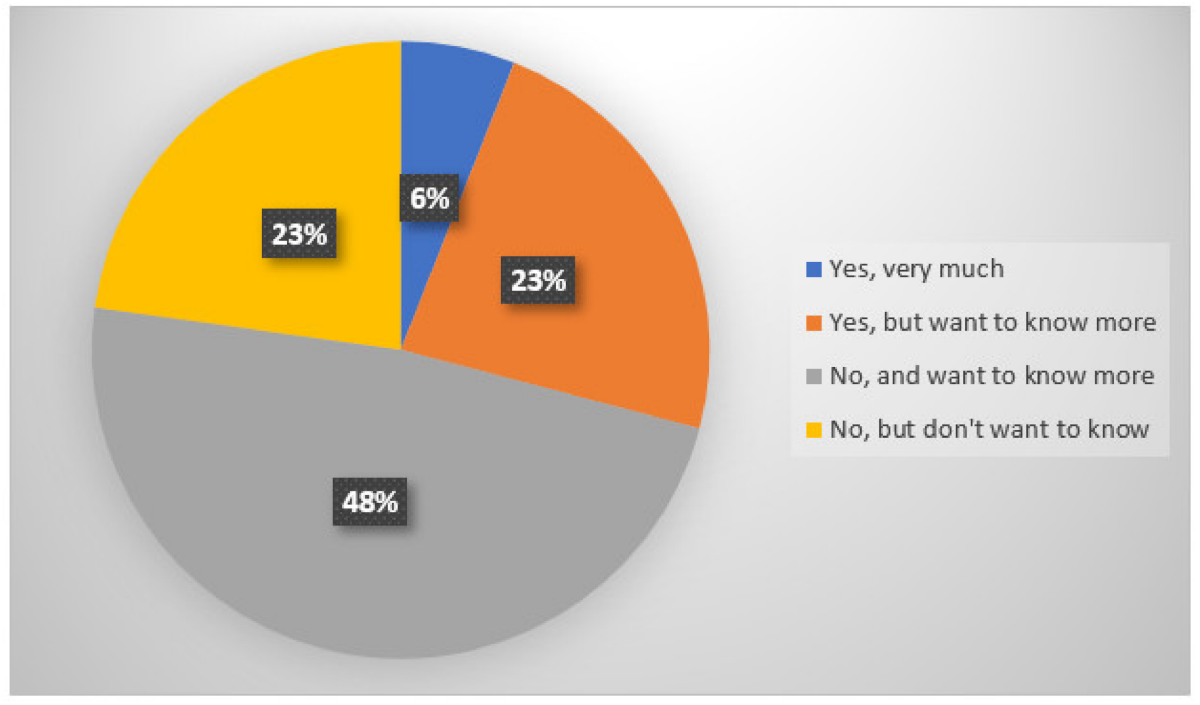

Figure 8. Do you think you know the EU well?

Recalling three major theories-image theory, agenda-setting theory, and stages of crisis communications-and the results from this study, we might be able to contribute in testing some elements of these theoretical aspects. In considering Mišík's three dimensions of perceptions, (1) relative power, (2) goal compatibility, and (3) cultural distance, the salient framings found from the results can be useful references. In assessing the EU's relative power to South Korea, the economic consequences frames in the Korean media imply that the EU's economic and trade power is equivalent to that of the US or China (such as FTA and Trump's trade war with other global actors). For the second dimension, goal compatibility, the same as the first dimension, economic consequences frames (such as EU-Korea trade or the ILO agreement), also hinted that both the EU and South Korea commonly seek a sound bilateral relations for drawing win-win results. For the last dimension, cultural distance, we could not find any possible relevant frames (responsibility or moral frames). This finding 
indicates that the EU and South Korea had no unpleasant historical past which might hinder the sound development of their bilateral relations. It also means that they can be sound partners when they have beneficial momentum (such as win-win situation after successful trade co-operations like FTA) for all. Recalling the results from the "Analysis of the perception of the EU and of EU's policies abroad" [6], the South Korean media still predominantly report on EU trade-related issues and project the EU's image created by its economic power to viewers [6] (p. 12). This point implies that Mišík's first dimension (relative power) is a key determining factor in shaping Korean perceptions of the EU. Hence, both the EU and South Korea are expected to establish mutually beneficial relations in the future, but ones limited to economic and trade relations.

The second theoretical perspective, the agenda-setting theory, mainly addresses the news media's impact in forming public awareness. In contrast to the Korean media representation of the EU, the Korean general public's awareness of the EU was not sufficiently established in this regard. Most the respondents (71\%) from the public opinion survey answered that they do not know the EU well (Figure 8). For extending Scheufele and Tewksbury's argument [28], at least economic consequences, human interests, and conflict frames would not be influential in forming the public judgment of the global actor. Possibly, responsibility or moral frames might be influential rhetorical devices in forming public awareness, but this awaits further investigation.

The last theoretical perspective, three phases of crisis communication, is useful to assess the stage of crisis communication between South Korea and the EU. Extending Coombs' explanation on the relationship between pre-crisis reputation (when favourable) and reputational capital [30], this study found that the EU did not lose its economic reputational capital in spite of its economic crises (Eurozone or Greek bailout). Recalling the three phases, the South Korean media was reactive only to the EU's economic crises. During the pre-crisis phase, the South Korean media was inclined to assess the possible impact of the union's crisis on the South Korean economy. Such media attitude extends to the crisis responses phase. Interestingly, in the post-crisis stage the South Korean media did not pay attention, since South Korea could not detect substantial impact on its economy. This perspective also implies that responsibility or moral frames emerge when the bilateral relations or cooperation yield negative results.

\section{Conclusions}

This paper aimed to address how the EU has been reported on in South Korean newspapers over the last decade (2010-2020). After collecting EU-related news from the six most representative newspapers for the ten years, this study analysed and visualised them using NodeXL. Semetko and Valkenburg's five experimental framing conditions were adopted as an analytic model [14]. The analysis results can be summarised in two points: First, the degree of the EU's exposure in South Korean media mainly depends on the news' direct influence or relevance to South Korea. Right after the signing and implementation of the free trade deal between the two parties, the EU attracted a great deal of attention of South Korean media in Period 1. Meanwhile, "pure" EU's regional issues such as the Syrian immigrant influx and Greece's referendum on bailout did not equally catch their attention (Period 2). Then again, in Period 3 the South Korean media were busy with predicting the consequences and impact of Brexit on the Korean economy.

Second, not much difference was found between conservative and liberal newspapers in their framing of EU news, but the latter dealt with the EU in a more diverse range of topics. This reflects the analysis results of EU news based on Semetko and Valkenburg's five experimental framings. Interestingly, out of the five frames-the conflict frame, human interest frame, economic consequences frame, morality frame, and responsibility frame-the EU news the Korean media reported was found to lack the morality and responsibility frames.

Such a tendency of Korean media seems to influence the Korean public's perception of the EU. As shown in Figure 7, the majority of the Korean respondents had the stance of "Neither good nor bad" toward the EU, although the bilateral relationship between the EU 
and Korea had evolved to be strategic partnership. As the Korean media report on the EU superficially, the Korean public seem to have a limited perception of the EU. As in Figure 8, a substantial number of Korean people think that they do not know much about the EU and want to know more about it. Even those who think they know the EU well still say they want to know more about it.

To address this perceptual disruption, both should pay more attention to enhancing accurate perceptions of the EU in South Korea. Korean news media could cover more diverse themes about the EU with multiple perspectives to establish a sound common understanding about the union. On the contrary, such attitudes should be found in the case of the South Korean media coverage of other countries, which needs further academic attention. Consequently, media practitioners such as editors and journalists need to cover international affairs based on thorough investigation in advance. Finally, this study suggests that South Korea should explore possible helpful grounds for further constructive cooperation with the EU. On this matter, the union's effort is also essential. With regard to this point, the EU delegation to the Republic of Korea could provide some helpful information outlets to boost the perceptions of the general public about the EU. The delegation could devise effective public diplomacy strategies with the aim of increasing Korean public awareness of the EU. When they show an active willingness to address their crisis, hopefully both sides can be closer partners despite their physical distance.

Author Contributions: Conceptualization, S.-W.Y. and S.W.C.; methodology, S.W.C.; software, S.W.C.; validation, S.-W.Y. and S.W.C.; formal analysis, S.W.C.; investigation, S.W.C.; resources, S.W.C.; data curation, S.W.C.; writing — original draft preparation, S.-W.Y. and S.W.C.; writing—review and editing, S.-W.Y. and S.W.C.; visualization, S.W.C.; supervision, S.-W.Y. and S.W.C.; project administration S.-W.Y. and S.W.C.; funding acquisition, S.-W.Y. All authors have read and agreed to the published version of the manuscript.

Funding: This research was funded by the research grant of The University of Suwon in 2019.

Institutional Review Board Statement: Ethical review and approval were waived for this study because the public opinion survey agency already obtained consent statements from all participants before the survey and their anonymity was fully guaranteed.

Informed Consent Statement: Informed consent was obtained from all subjects involved in the study.

Data Availability Statement: The media data presented in this study are openly available in BigKinds at https:/ / www.kinds.or.kr/ and the public opinion data are securely protected by the researchers.

Conflicts of Interest: The authors declare no conflict of interest. The funders had no role in the design of the study; in the collection, analysis, or interpretation of data; in the writing of the manuscript; or in the decision to publish the results.

\section{References}

1. European Commission. Countries and Regions: South Korea. Available online: https://ec.europa.eu/trade/policy/countriesand-regions / countries / south-korea / (accessed on 21 November 2020).

2. Chaban, N.; Kim, S.N.; Stats, S.; Sutthisripok, P. When Enough Is Enough? Dynamics of EU Representations in Asia-Pacific Print Media. Asia-Pac. J. EU Stud. 2004, 2, 173-193.

3. Chaban, N.; Chung, S.W. Public Perceptions of the EU in South Korea: Longitudinal Study (2004-2006). Asia-Pac. J. EU Stud. 2009, 7, 19-39.

4. Yoon, S.-W.; Chaban, N.; Chung, S.W. Trading Giant' and 'Economic Powerhouse'? Images of the EU in Korean Television News. Korean J. Contemp. Eur. Stud. 2010, 28, 283-329. [CrossRef]

5. Yoon, S.-W.; Lai, S.-Y. Far, Yet Close Enough? Dynamics of the EU Representations in East Asian Media. J. Contemp. Eur. Stud. 2015, 33, 245-280. [CrossRef]

6. Public Policy and Management Institute (PPMI), NCRE, and NFG Research Group. "Analysis of the Perception of the EU and EU's Policies Abroad: Comparative Public Opinion Survey Report", PPMI. 2015. Available online: https://ec.europa.eu/fpi/ sites/fpi/files/eu_perceptions_study_final_report_all_annexes.pdf (accessed on 28 January 2021).

7. Yoon, S.-W. Evolving Relations, Changing Perceptions? The Reflection of EU Representations in South Korea. J. Eur. Union Stud. 2020, 56, 191-219. [CrossRef]

8. Choi, H.-J. A Study on the Diversity of Korean Newspapers: Analyzing the Tendencies of Covering Three Major Issues. Korean J. Commun. Stud. 2010, 54, 399-426. 
9. Hallin, D.; Mancini, P. Comparing Media Systems: Three Models of Media and Politics; Cambridge University Press: Cambridge, UK, 2004.

10. Castro Herrero, L.; Humprecht, E.; Engesser, S.; Brüggemann, M.; Büchel, F. A Study on the Diversity of Korean Newspapers: Analyzing the Tendencies of Covering Three Major Issues. Int. J. Commun. 2017, 11, 4797-4823.

11. Reuters Institute. Digital News Report 2020. 2020. Available online: https://www.digitalnewsreport.org/ (accessed on 21 November 2020).

12. Park, S.-H.; Chung, S.W. Behind the Scenes: EU Images and Perceptions in South Korea. In Shaping the EU Global Strategy; Chaban, N., Holland, M., Eds.; Palgrave MacMillan: New York, NY, USA, 2019; pp. 213-234. [CrossRef]

13. Analysis of the Perception of the EU and of EU's Policies Abroad. Available online: https://ec.europa.eu/fpi/showcases/ analysis-perception-eu-and-eus-policies-abroad_en (accessed on 21 November 2020).

14. Semetko, H.; Valkenburg, P.M. Framing European Politics: A Content Analysis of Press and Television News. J. Commun. 2000, 50, 93-109. [CrossRef]

15. Silverstein, B.; Flamenbaum, C. Biases in the perception and cognition of the action of enemies. J. Soc. Issues 1989, 45, 51-72. [CrossRef]

16. Chaban, N.; Holland, M. Introduction. Partners and Perceptions. In Shaping the EU Global Strategy; Chaban, N., Holland, M., Eds.; Palgrave MacMillan: New York, NY, USA, 2019; pp. 1-25. [CrossRef]

17. Alexander, M.G.; Brewer, M.B.; Livingston, R.W. Putting stereotype content in context: Image theory and interethnic stereotypes. Personal. Soc. Psychol. Bull. 2005, 31, 781-794. [CrossRef]

18. Herrmann, R.K.; Keller, J.W. Beliefs, values, and strategic choice: US leaders' decisions to engage, contain, and use force in an era of globalization. J. Politics 2004, 66, 557-580. [CrossRef]

19. Mišík, M. How can Perception Help us to understand the Dynamic between EU Member States? The State of the Art. Asia Eur. J. 2013, 11, 445-463. [CrossRef]

20. Chung, S. Information Diffusion in YouTube Video Networks: The Case of Koreans' EU Perceptions. Korean J. EU Stud. 2019, 24, 25-47. [CrossRef]

21. Park, S.-H.; Chung, S.W. EU Perceptions from Korean YouTube videos before and after the Brexit Referendum. In Changing Perceptions of the EU at Times of Brexit: Global Perspectives; Chaban, N., Niemann, A., Speyer, J., Eds.; Routledge: London, UK, 2020; pp. 247-264.

22. Chung, S. A New Dimension in South Korean Perceptions of the EU: Focusing on Sentiment and Semantic Networks of Korean YouTube Videos. J. Eur. Union Stud. 2020, 56, 221-251. [CrossRef]

23. McCombs, M.; Reynolds, A. News influence on our pictures of the world. In LEA's Communication Series. Media Effects: Advances in Theory and Research; Bryant, J., Zillmann, D., Eds.; Lawrence Erlbaum Associates Publishers: Mahwah, NJ, USA, 2002; pp. 1-18.

24. McCombs, M.; Shaw, D. The Agenda-Setting Function of Mass Media. Public Opin. Q. 1972, 36, 176-187. [CrossRef]

25. Hastie, R.; Park, B. The Relationship between Memory and Judgment Depends on Whether the Judgment Task is Memory-based or on-line. Psychol. Rev. 1986, 93, 258-268. [CrossRef]

26. Iyeanger, S.; Kinder, D. News that Mattes: Television and American Opinion; University of Chicago Press: Chicago, IL, USA, 1987.

27. Iyeanger, S. The Accessibility Bias in Politics: Television News and Public Opinion. Int. J. Public Opin. Res. 1990, 2, 1-15. [CrossRef]

28. Scheufele, D.; Tewksbury, D. Framing, Agenda-setting and Priming: The Evolution of Three Media Effects Models. J. Commun. 2007, 57, 9-20. [CrossRef]

29. Price, V.; Tewksbury, D. News values and public opinion: A theoretical account of media priming and framing. In Progress in Communication Sciences: Advances in Persuation; Barett, G., Boster, F., Eds.; Ablex: Greenwich, CT, USA, 1997; pp. 173-212.

30. Coombs, T. Protecting Organization Reputations during a Crisis: The Development and Application of Situational Crisis Communication Theory. Corp. Reput. Rev. 2007, 10, 163-176. [CrossRef]

31. Fombrum, C.; van Reil, C. Fame E Fortune: How Successful Companies Build Winning Reputations; Prentice-Hall Financial Times: New York, NY, USA, 2004.

32. Alsop, R. The 18 Immutable Laws of Corporate Reputation: Creating, Protecting, and Repairing Your Most Valuable Asset; Free Press: New York, NY, USA, 2004.

33. Dowling, G. Creating Corporate Reputations: Identity, Image, and Performance; Oxford University Press: New York, NY, USA, 2002.

34. Chung, S.; Lee, J. Building the Pillars of the EU-South Korea Strategic Partnership. Asia Eur. J. 2019, 17, 327-340. [CrossRef]

35. Korea Press Foundation. Media Users in Korea. 2020. Available online: https://www.kpf.or.kr/front/research/consumerDetail. do (accessed on 16 January 2021).

36. BigKinds. News Bigdata and Analysis. Available online: https://www.bigkinds.or.kr/ (accessed on 26 November 2020).

37. UiPath. About Data Scraping. Available online: https://docs.uipath.com/studio/v2020.4/docs/about-data-scraping (accessed on 26 November 2020).

38. Chung, S.W.; Park, S.-H. A Study on EU images reflected on the Korean media: Focusing on Major Dailies and Economic Paper. Korean J. Contemp. Eur. Stud. 2016, 28, 299-330. [CrossRef]

39. Huang, Y.-H.C.; Wu, F.; Cheng, Y. Crisis Communication in Context: Cultural and Political Influences Underpinning Chinese Public Relations Practice. Public Relat. Rev. 2015, 42, 201-213. [CrossRef] [PubMed]

40. Van Atteveldt, W. Semantic Network Analysis: Techniques for Extracting, Representing and Querying Media Content; BookSurge: Charleston, SC, USA, 2008.

41. Loebner, S. Understanding Semantics; Arnold: London, UK, 2002. 
42. Feldman, R.; Sanger, J. The Text Mining Handbook: Advanced Approaches in Analyzing Unstructured Data; Cambridge University Press: Cambridge, UK, 2007.

43. Drieger, P. Semantic Network Analysis as a Method for Visual Text Analytics. Procedia-Soc. Behav. Sci. 2013, 79, 4-17. [CrossRef]

44. Raj, M. How Important are Semantic Networks in Artificial Intelligence. Analytics India Magazine. 23 January 2019. Available online: https: / / analyticsindiamag.com/semantic-networks-ai/\#: \{\}:text=Semantic\%20networks\%20became\%20popular\%20 in,represents \%20knowledge\%20r\%20supports\%20reasoning.\&text=Relationships\%20provide\%20the $\% 20$ basic\%20needed, not $\% 20$ needed $\% 20$ to $\% 20$ be $\% 20$ concrete (accessed on 1 December 2020).

45. NodeXL Korea. Catching Up NodeXL; Paradigm Books: Seoul, Korea, 2015. (In Korean)

46. Goffman, E. Frame Analysis: An Essay on the Organization of Experience; Harper and Row: New York, NY, USA, 1974.

47. Gitlin, T. The Whole World is Watching: Mass Media in the Making and Unmaking of the New Left; University of California Press: Berkeley, CA, USA, 1980.

48. Gamson, W.A.; Modigliani, A. The Changing Culture of Affirmative Action. In Research in Political Sociology; Braungart, R., Ed.; JAI: Greenwich, CT, USA, 1987; Volume 3, pp. 137-177.

49. Gamson, W.A.; Modigliani, A. Media Discourse and Public Opinion on Nuclear Power: A Constructionist Approach. Am. J. Sociol. 1989, 95, 1-37. [CrossRef]

50. Pan, Z.; Kosicki, G.M. Framing Analysis: An Approach to News Discourse. Political Commun. 1993, 10, 55-75. [CrossRef]

51. Entman, R. Framing: Toward Clarification of a Fractured Paradigm. J. Commun. 1993, 43, 51-58. [CrossRef]

52. Neuman, W.R.; Just, M.R.; Crigler, A.N. Common Knowledge: News and the Construction of Political Meaning; University of Chicago Press: Chicago, IL, USA, 1992.

53. Iyengar, S. Is Anyone Responsible? How Television Frames Political Issues; University of Chicago Press: Chicago, IL, USA, 1991.

54. Hansen, D.; Shneiderman, B.; Smith, M.; Himelboim, I. Analyzing Social Media Networks with NodeXL, 2nd ed.; Morgan Kaufmann: Cambridge, MA, USA, 2020.

55. Lehmann, F. Semantic Networks. Comput. Math. Applic. 1992, 23, 1-50. [CrossRef]

56. Coombs, W.T. Crisis Management and Communications (Updated September 2014). Institute for Public Relations. 23 September 2014. Available online: https://instituteforpr.org/crisis-management-communications/ (accessed on 17 December 2020). 